\title{
Empirical Study on the Influence among Corporate Sponsorship, Organizational Commitment, Organizational Cohesiveness and Turnover Intention
}

\author{
De-Chih Lee ${ }^{1}$, Li-Mei Hung ${ }^{2}$ \& Mei-Ling Chen ${ }^{3}$ \\ ${ }^{1}$ Department of Information Management, Da-Yeh University, Changhua County, Taiwan \\ ${ }^{2}$ Department of Hospitality Management, Hungkuang University, Taichung City, Taiwan \\ ${ }^{3}$ Department of Applied English, Hungkuang University, Taichung City, Taiwan \\ Correspondence: Li-Mei Hung, Department of Hospitality Management, Hungkuang University, No.34 \\ Chung-Chie Rd., Sha Lu, Taichung City 443, Taiwan (R.O.C.). Tel: 886-4-2631-8652. E-mail: \\ hlm@sunrise.hk.edu.tw
}

Received: January 30, 2012 Accepted: March 8, 2012 Online Published: May 24, 2012

doi:10.5539/jms.v2n2p43 URL: http://dx.doi.org/10.5539/jms.v2n2p43

\begin{abstract}
This study utilized employees in foreign companies as the study subject to analyze the relationships between corporate sponsorship, organizational commitment, organizational cohesiveness and turnover intention. The results indicated that: employees with a higher level of organizational commitment have a lower level of turnover intention; organizational commitment can enhance organizational cohesiveness; organizations with a higher level of organizational cohesiveness will have a lower level of turnover intention; for organizations with the same level of organizational commitment, employees will have a lower level of turnover intention if their corporate sponsorship is higher than their counterpart whose organization has a lower level of corporate sponsorship. Our result revealed that even though the score of organizational commitment is low among the sample, the hypothesis that organizational commitment and organizational cohesiveness both exert positive influences is supported.
\end{abstract}

Keywords: organizational commitment, organizational cohesiveness, turnover intention, corporate sponsorship

\section{Introduction}

All enterprises consist of employees, and talents are the foundation that powers up an enterprise (Schneider, 1987). Influenced by environmental factors, either internal or external to an enterprise, employees may choose to leave the organization, which in turn generates a turnover problem for the organization (Garkovich \& Greider, 1994). Every enterprise faces this problem and a high turnover rate will increase HR costs (recruiting, screening and training) and cause shortstaffing, which will directly disrupt personnel stability in an organization (Krackhardt \& Porter, 1981). When the turnover rate exceeds a certain level, the organization will suffer from work loss, and a lot of passive influences will severely affect the work atmosphere (Ferguson, 1986). Thus, how to retain employees becomes an important task that each enterprise should seriously pay special attention to.

There are a lot of reasons employees may choose to leave their organization. Poor organizational cohesiveness among employees (Robinson \& Carron, 1982); employees do not understand organizational culture or can not fit in to the organization; or lack a sense of belonging (O'Reilly, Chatman \& Caldwell, 1991) will all drive employees away from their organization. Mullen and Cooper (1994) indicated that when organizational cohesiveness is high in an organization, its members will be proud of being a part of their organization and continue to stay at the organization, and they are more willingly to work together with other members for the goal of the organization.

Another important reason that employees choose to leave their organization is that employees can not identify themselves with their organization (Gooley, 2001). Organizational commitment primarily describes the level of approval, level of contribution, sense of identification, sense of fitting in, loyalty and level of commitment employees have toward their organization (Meyer, Paunonen, Gellatly, Goffin \& Jachson, 1989). If employees do not understand the company culture, cannot fit in their organization or lack a sense of identification, they will 
choose to leave their organization (Autry \& Daugherty, 2003). According to Randall (1990), the turnover rate among employees with low organization commitment is typically high, but Aryee, Wyatt and Min (1991) argued that organizational commitment only indirectly affects turnover intention. There are even studies pointing out that organizational commitment and turnover behaviors are not significantly correlated (Sackett; Harris \& Orr, 1986). Thus, whether organizational commitment will influence employee turnover intention is an area worthy of clarification.

In order to retain employees, alleviate and resolve employee turnover predicaments, boost organizational performance and maintain competitive advantages, more and more organizations start to take their corporate social responsibility and obligation seriously and commit to systematic and long term sponsorship activities (Dwight \& Richard, 1997). Yet, this kind of sponsorship behaviors may adversely reduce employee salary and benefits. Can employees approve these behaviors? Do they help to retain employees, or cause employees to leave the organization? This is an interesting issue. Thus, this study will discuss whether corporate sponsorship behaviors will alter influences that organizational commitment and organizational cohesiveness have on turnover intention.

\section{Literature Review}

\subsection{Turnover Intention}

Turnover intention refers to the tendency that employees are leaving the organization that they are currently working for, and this tendency will ultimately lead to turnover behaviors; turnover intention is strongly correlated to turnover behavior, meaning that turnover intention can serve as a sign of a turnover behavior and is the most suitable variable for predicting a turnover behavior (Mobley, 1977). Hom (2000) specifically pointed out in his research that turnover intention is a determining factor for turnover behavior. In other words, turnover intention is the serious thought, intention, or perception in the mind of employees to look for a new job elsewhere accompanied by free will and psychological motive to leave their current work environment because they are not satisfied with their current job conditions (Chang, 2008).

According to Ferguson (1986), turnover can be classified as voluntary turnover and involuntary turnover. For this study, turnover intention refers to a psychological indication to leave a working environment that leads to turnover behavior before employees actually quit their job (Caplan, Cobb, French, Harrison, \& Pinneau, 1975).

\subsection{Organizational Cohesiveness}

Cohesion, originated from cohaesus, a Latin word, means binding intimately and closely and is a dynamic process (Chidambaram \& Jones, 1996). In other words, cohesion refers to the dynamic process in which team members work closely to accomplish objectives and goals of their team (Chelladurai, P., \& Carron, 1982). Cohesion also indicates the total strength measuring how much team members are willing to stay in their team (Corey, 1992) and the level of commitment team members have for their team (Vander, 1985). According to a study conducted by Clark, Hartline and Jones (2009), cohesion is emotional and mental power that motivates employees to stay within a group and tightly binds the hearts of teammates together. Cohesion is the most influential characteristic in group interactions, and it is also a dynamic process; team members with a high level of cohesion are more likely to support one another and work together to attain a common goal (Keller, 1986); it is an important indicator of team spirit and a power to retain team members to stay within a group (Robbins, 1993). When a team has a high level of cohesion, its sense of belonging is comparatively higher (Carron \& Brawley, 1985). Its members are more willing to stay within the group and work with other members (Mullen \& Cooper, 1994). If employees do not experience a sufficient level of cohesion, then there is a strong possibility that employees will leave their organization (O'Reilly et al., 1991). Based on this rationale, organizational cohesiveness has a negative impact on turnover intention. Thus, in this study, we hypothesized that:

\section{H1: organizational cohesiveness is negatively correlated to turnover intention.}

\subsection{Organizational Commitment}

Organizational commitment refers to the level one individual identifies himself or herself with an organization and his or her level of devotion (Mowday, Porter \& Steers, 1974). Members with strong organizational commitment have three tendencies: 1) firmly believe in and accept the objective and value of their organization; 2) are more willing to contribute to their organization; and 3) eager to be a member in the organization. Thus, organizational commitment reflects the degree of loyalty and contribution an individual has for the organization, determines how much one individual would commit to an organization and represents the attitude or tendency of one individual to connect with an organization (Mowday, Porter \& Steers, 1982). Ferris and Aranya (1983) argued that organizational commitment is a task and goal. If the mission of an organization is congruent with the 
ideal of its members, then it is easier for them to perceive strong organizational cohesiveness (Smith et al., 1983). If the level of identification and support is low among team members, then it is highly likely that they have a lower level of organizational cohesiveness (Lawler \& Yoon 1993, 1996).

Based on the above viewpoints, the level of organizational commitment will exert a positive and direct influence on the level of organizational cohesiveness of members. Thus, we hypothesized that:

\section{H2: Organizational commitment can effectively enhance organizational cohesiveness.}

Additionally, according to a study of medical professionals by Wagner (2007), organizational commitment can more accurately measure the employee turnover rate than job satisfaction, and this conclusion confirms the finding from Yousef (2000) - organizational commitment can better predict intention to stay than job satisfaction can. Thus, we hypothesized that:

\section{H3: Organizational commitment is negatively correlated to turnover intention.}

\subsection{Corporate Sponsorship}

The word sponsorship can trace its root back to as early as the ancient Greek and Rome period (Carrigan, 1997). In the beginning, sponsorship was perceived as a kind of begging behavior where profitable enterprises donated financial aid or physical goods to certain groups. However, in recent years, corporate sponsorship is viewed by enterprises as a marketing tool and means for corporate sustainable development (Bloom, Hoeffler, Keller, \& Meza, 2006). Through value-exchanging activities, sponsors and the sponsored work together to generate greater benefits than they can alone (Johnson \& Zinkhan, 1990). Thus, the ultimate goal of corporate sponsorship as a strategy is to win over all kinds of desired relationships, meaning that enterprises provide resources (financial aid, manpower, equipment, and services) as a means for them to perform certain activities or acquire direct relationships associated with these activities. With these relationships, enterprises can form reciprocal relationships with other parties and achieve the goal of corporate marketing, media exposure, or other similar purposes (Shandler \& Shani, 1989; Stotlar, 1993; McCavarille \& Copeland, 1994). Corporate sponsorship is mostly charitable and philanthropic in nature, but most scholars argue that when enterprises sponsor certain events, they only provide agenda, activity, or event specific-resources (financial aid, equipment, and manpower) for certain commercial purposes such as improving corporate image and marketing objectives (ex. brand awareness), acquiring direct relationships with the sponsored events to achieve corporate marketing purposes or media goals or obtaining certain commercial opportunities (Gardner \& Shuman, 1988; Sandler \& Shani, 1989; Meenaghan, 1991). Dwight \& Richard (1997) went a step further and indicated that in the last five years, corporate sponsorship not only yielded profits, but has also become a new revenue source of sponsoring enterprises. On the contrary, Meenaghan (2001) argued that corporate sponsorship has drawbacks (ex. unfair profit distribution) that employees may not approve its positive values, may not build up organizational cohesiveness among members to work together as a team or even strengthen turnover intention to leave their team. In previous studies, corporate sponsorship could exert two different kinds of influences on employee turnover intention. Therefore, corporate managers should evaluate their ability and enhance corporate cohesiveness among employees based on employee level of specialties, corporate resources and abilities to deal with relationships internal or external to their organization, before providing corporate sponsorship (Gwinner, 1999). If the senses of belonging and corporate cohesiveness are both low among employees, then it is highly likely that they will disapprove or do not support goals of their organization, which will lead to a higher level of turnover intention (O'Reilly, Caldwell \& Barnett, 1989; Jaffrey \& Charles, Rajan, 1989). As a result, corporate sponsorship and organizational cohesiveness will both influence turnover intention. Thus, we hypothesized that:

\section{H4: Corporate sponsorship and organizational cohesiveness both exert significant influence on turnover} intention.

\section{Measure}

\subsection{Turnover Intention}

This study utilized three employee-related dimensions to measure turnover intention: 1) intention to stay at the current job; 2) intention to quit the current job; and 3) intention to transfer to another position. Most literature reviewed for this study adopted the questionnaire designed by Mobley (1987) as the measurement instrument. This questionnaire primarily measures changes that employees perceive toward corporate images, turnover intention, behaviors that employees use to search for other jobs and possibility of finding another job. Although Michaels and Spencer (1982), Johnston and Futrell (1989) all proposed revised questionnaires, they are very similar to the one designed by Mobley. This study adopted the definition of turnover intention by Mobley, Horner \& Hollingsworth (1978). They defined turnover intention as the strength of employee intention to 
voluntarily terminate employment contracts and leave the current organization to seriously search for other job opportunities after employees have been in their position for a period of time. This intention, once strengthened, will cause employees to leave their current position, lose benefits provided to them by the current organization and terminate their relationship with the current organization. This definition is consistent with the idea behind the questionnaire developed by Mobley. Due to linguistic and cultural differences, this study modified the turnover questionnaire developed by Mobley (1987). The questionnaire includes four parts: 1) strength of turnover intention; 2) motivational strength to search for other jobs (either homogenous or heterogeneous); 3 ) level of influence of the number of external job opportunities available; and 4) intentional strength of leaving the current job. The questionnaire has ten questions, adopts the Likert five-point scale (strongly disagree, disagree, average, agree, strongly agree), and each scale level is assigned with a point from one to five. All points were summed up and then averaged. A higher score indicates that the level that the respondent perceives organizational support is higher. All questions are listed below, and question seven and nine are reverse questions.

(1) I think about quitting my current job all the time.

(2) I would physically like to apply for jobs with other companies.

(3) I might quit my job very soon.

(4) I thought about asking around for job opportunities recently.

(5) If I am offered a job with a better compensation package, I will quit my current job for sure.

(6) I will not leave my current company if other companies or organizations actively offer me a position.

(7) I will not quit my job no matter how my company has changed (R).

(8) I will consider changing my job if my current job location is far from my home.

(9) I do not think my job is a permanent job for me (R).

(10) I will quit my current job because of arguments or poor communications with my supervisor or colleagues.

\subsection{Organizational Cohesiveness}

LeUnes and Nation (1989) indicated that there are four instruments frequently adopted to measure organizational cohesiveness in sports contests: 1) Sport Cohesiveness Questionnaire, or SCQ; 2) Task Cohesiveness Questionnaire, or TCQ; 3) Multidimensional Sport Cohesiveness Instrument, or MSCI; and 4) Group Environment Questionnaire, or GEQ. Based on the definition by Carron, Widmeyer, Brawley (1985), this study defined organizational cohesiveness as the dynamic power that enables team members to attract one another and work together for their team. Thus, the GEQ by Carron, Widmeyer and Brawley (1985) is excellent for use in this study and the GEQ was revised in this study to measure organizational cohesiveness. This questionnaire has ten questions and adopts the Likert five-point scale. All points were summed up and then averaged. A higher score indicates that a higher level of organizational cohesiveness exists among employees. All questions are listed below, and question three, eight, and nine are reverse questions.

(1) I enjoy participating in organizational and group activities.

(2) I am very pleased with the time spent on team activities hosted by my organization.

(3) I am disappointed with the thought that my organization is trying to achieve the administrative purpose (R).

(4) My best friends are also in the same organization as I am.

(5) In my team, I have sufficient opportunities to improve my personal performance.

(6) I like the way my team handles tasks.

(7) I think my team is a meaningful group.

(8) My team members prefer working on their own rather than working together as a group (R).

(9) Our group performance is inconsistent with team member expectations (R).

(10) Team members enjoy spending free time together (outside of group activities and training sessions)..

\subsection{Organizational Commitment}

The Organizational Commitment Questionnaire, or OCQ, by Porter, Steers, Mowday, and Boulian (1974) is the most widely utilized questionnaire. It can measure the degree that 1) team members approve organizational objectives and values; 2) they commit to the goals of a group; and 3) members are willing to continue staying at 
their organization. Thus, this study has revised the OCQ to better meet the purpose of this study. This questionnaire has 15 questions and adopts the Likert five-point scale (strongly disagree, disagree, average, agree, strongly agree), and each scale level is assigned with a point from one to five. All points were summed up and then averaged. A higher score indicates a higher level that the respondent has a higher level of organizational commitment. All questions are listed below, and question seven, eight, nine and eleven are reverse questions.

(1) I found that the goal that my team emphasizes is very similar to the one my organization emphasizes.

(2) I feel proud every time I talked to people about the vision of my organization.

(3) I can utilize my talent within my team.

(4) I am very grateful to work at my team.

(5) To me, my team is the best one in my organization.

(6) I often tell my friends that my organization is the best place to work.

(7) It will do no good to my future if I continue working to achieve the goals of my organization.

(8) I do not mind being reassigned to another team as long as it shares similar organizational traits and conditions (R).

(9) I have no loyalty toward my organization (R).

(10) I agree with most corporate policies relevant to my team members.

(11) It is an obvious mistake that I work hard to realize my organizational goals (R).

(12) I am willing to take on all tasks assigned to me by my team leader.

(13) I am willing to put extra effort into my work and help my organization to develop and succeed.

(14) I am genuinely concerned about the future development of my organization.

(15) I work very hard and treat the benefits of my organization as my own.

\subsection{Corporate Sponsorship}

Since the study subject is organizational employees (and team members) and the purpose is to evaluate their attitudes, perceptional assessment and cognition toward corporate sponsorship, variables measured in the questionnaire were chosen utilizing questions from the sponsorship attitude measurement questionnaire by Speed and Thompson (2000) and the sponsorship goal cognitization and perception questionnaire by Stipp and Schiavone (1996). This questionnaire has 15 questions and adopts the Likert five-point scale (strongly disagree, disagree, average, agree, strongly agree), and each scale level is assigned with a point from one to five. All points were summed up and then averaged. A higher score indicates a higher level that the respondent has a higher level of awareness toward corporate sponsorship. All questions are listed below.

(1) I think that all kinds of event my team has sponsored are important.

(2) I like the fact that my team has to support sponsorship events.

(3) I hope to participate in all sponsorship events for my team.

(4) I support all sponsorship events for my team.

(5) I feel that all sponsorship events supported by my team are important since I approve all sponsorship events.

(6) I pay a lot of attention to news associated with sponsorship events that my team is involved in.

(7) I feel that corporate sponsorship can increase brand awareness of my company.

(8) I feel that corporate sponsorship is a method that enterprises can use to strengthen their corporate social responsibility.

(9) I think that corporate sponsorship will attract media attention (so they will write a report and promote sponsoring enterprises).

(10) I think all events that my organization has sponsored are meaningful.

(11) I think my organization can make profits from events sponsored.

(12) I think my organization can attract customer attention from events sponsored.

(13) I feel pleasurable about the fact my organization sponsors public events.

(14) I feel positive about corporate image for organizations sponsoring public events. 
(15) I believe that all organizations that have sponsored public events are good organizations.

\subsection{Respondent Demographic Variables}

In addition to all variables above, the questionnaires also collect demographic information of respondents, including gender (male, female); age (actual age); marital status (married, unmarried); level of education (junior high school and lower, high school (vocational school), university (junior college), master (PhD)); industry (trade, service, transportation and warehousing, banking and insurance, dining, and other); years of experience (counting only years at the current company); and income level (below NTD\$20,000, NTD\$20,001 40,000, NTD $\$ 40,001 \sim 60,000$, NTD $\$ 60,001-80,000$, NTD $\$ 80,001-100,000$, and NTD\$100,001 or higher)

\section{Study Subject and Confirmatory Factor Analysis}

\subsection{Study Subject and Sampling Method}

The study subject of this study are employees from foreign enterprises in Taiwan, including CitiBank, ABN AMRO Bank, Bank of Scotland, SBC, Standard Chartered Bank, American International Bank, Fubon Financial, MassMutual Mercuries Life, Carrefour, Costco, B\&Q, Watsons, fast food restaurant chains (McDonald's, MOS BURGER, Domino's), Allianz, New York Life Insurance, Zurich Financial Services, State Street Corp, OCBC Bank and BNP Paribas.

To assess the applicability of the questionnaires and identify ambiguous questions for revision, this study utilized the random sampling approach in the trial test. Companies were first randomly selected and contacted by phone to seek their assistance for sending questionnaires in the trial test. Descriptions of testing methods as well as all relevant testing details (ex. questionnaire collection and how to fill out questionnaires) were provided to the contact window within the contacted companies. For the official test, 1 3 teams were chosen from each selected company. On average, each team received 20 copies of the questionnaire and a total of 750 copies were sent out. Only full-time employees (still employed at the time questionnaires were sent out) who have worked at their current organizations for more than one year were selected and their age ranged from 20 to 60 .

\subsection{Confirmatory Factor Analysis}

In the trial test, 250 questionnaires were collected and AMOS 7.0 was used to perform the confirmatory factor analysis. For factor loading, this study adopted the range classification proposed by Comrey and Lee (1992) acceptable: $0.45 \sim 0.55$; good: $0.55 \sim 0.63$; very good: $0.63 \sim 0.71$; and extremely good: 0.71 or higher. Only answers with factor loading of 0.45 or higher were counted. For the model quality, this study utilized the two indexes suggested by Formell and Laker (1981): construct reliability and variance extracted for measurement. For the model fit, the acceptable value need to be smaller than five (CMIN/DF) (Formell and Laker 1981), GfI, CFI and NFI need to be larger than 0.9 (Bentler and Bonett, 1980; Marsh and Hocevar, 1983) and RMSEA needs to be smaller than 0.1. Table 1 summarizes all goodness of fit indexes for all variables.

From Table 1, it can be seen that the goodness of fix indexes of all variables are within the acceptable range. Additionally, factor loading of each variable is between 0.45 and 0.95 and the convergent validity falls in the acceptable range.

Table 1. Indexes of all variables

\begin{tabular}{lcccc}
\hline & $\begin{array}{c}\text { Organizational } \\
\text { Commitment }\end{array}$ & $\begin{array}{c}\text { Organizational } \\
\text { Cohesiveness }\end{array}$ & $\begin{array}{c}\text { Corporate } \\
\text { Sponsorship }\end{array}$ & $\begin{array}{c}\text { Turnover } \\
\text { Intension }\end{array}$ \\
\hline CMIN/DF & 3.723 & 4.824 & 4.163 & 4.721 \\
GFI & 0.918 & 0.943 & 0.922 & 0.928 \\
CFI & 0.886 & 0.905 & 0.935 & 0.940 \\
NFI & 0.927 & 0.888 & 0.891 & 0.932 \\
RMSEA & 0.061 & 0.086 & 0.063 & 0.089 \\
Construct Validity & 0.836 & 0.777 & 0.859 & 0.796 \\
Variance extracted & $61.29 \%$ & $57.37 \%$ & $65.55 \%$ & $53.59 \%$ \\
\hline
\end{tabular}

\section{Data Analysis and Result}

\subsection{Sample Distribution}

The study subjects are full-time employees at foreign companies who have been with their current company for more than one year. A total of 750 questionnaires were sent out in March, 2010 and collected in June 2010. 674 
effective questionnaires were collected ( $89.9 \%$ collection rate). 23 ineffective questionnaires (with unanswered questions, duplicated entries and inappropriate marks) were excluded, and the number of effective questionnaires was 651 (86.6\% valid questionnaire collection rate.) The sample distribution is listed in Table 2.

Table 2. Sample distribution

\begin{tabular}{|c|c|c|c|c|c|c|c|}
\hline Variable & Classification & $\mathrm{n}$ & Percentage & Variable & Classification & $\mathrm{n}$ & Percentage \\
\hline \multirow{6}{*}{ Gender } & Male & 248 & $38 \%$ & \multirow{3}{*}{ Marital Status } & Married & 310 & $47.7 \%$ \\
\hline & Female & 403 & $62 \%$ & & Unmarried & 341 & $52.3 \%$ \\
\hline & 20 or less & 43 & $6.6 \%$ & & 5 or less & 179 & $27.0 \%$ \\
\hline & $21-25$ & 69 & $10.5 \%$ & \multirow{3}{*}{$\begin{array}{l}\text { Years of Work } \\
\text { Experience }\end{array}$} & $6-10$ years & 152 & $23.3 \%$ \\
\hline & $26-30$ & 139 & $20.2 \%$ & & $11-15$ years & 150 & $23 \%$ \\
\hline & $31-35$ & 105 & $16.1 \%$ & & $16-20$ years & 118 & $18.1 \%$ \\
\hline \multirow{7}{*}{ Age } & $36-40$ & 93 & $14.8 \%$ & \multirow{7}{*}{$\begin{array}{l}\text { Level of } \\
\text { Education }\end{array}$} & More than 21 & 52 & $8.6 \%$ \\
\hline & $41-45$ & 94 & $14.9 \%$ & & Junior High School or Lower & 26 & $3.9 \%$ \\
\hline & $46-50$ & 57 & $8.7 \%$ & & $\begin{array}{l}\text { Senior High School(including } \\
\text { vocational school) }\end{array}$ & 33 & $5 \%$ \\
\hline & $51-55$ & 40 & $6 \%$ & & College & 37 & $5.6 \%$ \\
\hline & More than 56 & 11 & $2.2 \%$ & & University & 295 & $45.3 \%$ \\
\hline & $20,001-40,000$ & 47 & $7.2 \%$ & & Master (PhD) & 260 & $40.2 \%$ \\
\hline & $40,001-60,000$ & 245 & $37.6 \%$ & & Trade & 65 & $9.9 \%$ \\
\hline \multirow{6}{*}{$\begin{array}{l}\text { Income } \\
\text { Level }\end{array}$} & $60,001-80,000$ & 158 & $24.2 \%$ & \multirow{4}{*}{ Industry } & Service & 136 & $20.3 \%$ \\
\hline & $80,001-100,000$ & 142 & $21.8 \%$ & & Transportation and Warehousing & 94 & $14.4 \%$ \\
\hline & $80,001-100,000$ & 36 & $5.5 \%$ & & Banking and Insurance & 274 & $42.1 \%$ \\
\hline & $\begin{array}{l}\text { More than } \\
100,001 \text { dollars }\end{array}$ & 23 & $3.7 \%$ & & Dining & 82 & $13.3 \%$ \\
\hline & & & & \multirow{2}{*}{ Position } & Managerial & 426 & $65.5 \%$ \\
\hline & & & & & Non-Managerial & 225 & $34.5 \%$ \\
\hline
\end{tabular}

\subsection{Correlation Coefficient Analysis}

Table 3 lists Pearson Correlation Coefficient, Mean, and Standard Deviation among variables. The mean of each variable is smaller than 3, and this result indicates that the study subjects in general have a lower level of organizational commitment, organizational cohesiveness and approval of corporate sponsorship. However, researched companies do not need to be especially concerned about employee turnover, since the score measuring turnover intention for all respondents are, on average, lower. This, when combined with statistics of all explanatory variables negatively correlated to turnover intention, supports the initial hypothesis in this study.

Table 3. Correlation coefficient among variables

\begin{tabular}{llllll}
\hline Correlation Coefficient & $\begin{array}{l}\text { Standard } \\
\text { Deviation }\end{array}$ & Mean & $\begin{array}{l}\text { Organizational } \\
\text { Commitment }\end{array}$ & $\begin{array}{l}\text { Organizational } \\
\text { Cohesiveness }\end{array}$ & $\begin{array}{l}\text { Turnover } \\
\text { Intension }\end{array}$ \\
\hline Organizational Commitment & 0.68 & 2.74 & & & \\
Organizational Cohesiveness & 0.92 & 2.26 & $.494^{* *}$ & & \\
Turnover Intension & 0.29 & 1.66 & $-.406^{*}$ & $-.307^{* *}$ & \\
Corporate Sponsorship & 0.98 & 2.93 & $.350^{* *}$ & $.555^{* *}$ & $-.48^{*}$ \\
\hline
\end{tabular}

$* \mathrm{P}<0.05, * * \mathrm{P}<0.01$

\subsection{Regression Analysis}

As variable scores were summed up and then averaged and variables were measured utilizing the 5-point Liker scale to examine the strength among variables, unstandardized regression analysis was not utilized in the test. Table 4 shows the result of regression analysis. From Table 4, the regression-coefficient between organizational cohesiveness and turnover intention is $\beta=-0.95, R^{2}=0.529 \quad(\mathrm{p}<.05)$, supporting H2 statistically; the regression-coefficient between organizational commitment and organizational cohesiveness $(p<.05) \beta=-0.195$, 
$R^{2}=0.508$, supporting H1. Thus, organizational cohesiveness and organizational commitment can effectively lower employee turnover intention. When testing the interactive effects that corporate sponsorship and organizational cohesiveness each have on turnover intention, to ensure the reliability of multiple regression, we also performed a collinearity test. The VIF value is smaller than 2 and no serious collinearity issues were identified. From Model 3, both organizational cohesiveness and corporate sponsorship exert negative influences on turnover intention. Meanwhile, the regression coefficient of interaction between corporate sponsorship and organizational cohesiveness is $\beta=-0.241, R^{2}=0.539(p<.05)$. This also yields negative influences, and this supports $\mathrm{H} 5$ statistically.

Table 4. Regression analysis

\begin{tabular}{lllllc}
\hline & \multicolumn{3}{c}{ Turnover Intension } & & $\begin{array}{c}\text { Organizational } \\
\text { Cohesiveness }\end{array}$ \\
\cline { 2 - 6 } & Mode 1 & Mode 2 & Mode 3 & Mode 4 & Mode 5 \\
\cline { 2 - 6 } & $-.95^{* * *}$ & $-.018^{* *}$ & $-.101^{*}$ & & \\
Organizational Cohesiveness & & & & $-.98^{* *}$ & $.195^{* * *}$ \\
$\begin{array}{l}\text { Organizational Commitment } \\
\text { Corporate Sponsorship }\end{array}$ & & $-.088^{* *}$ & $-.022^{*}$ & & \\
$\begin{array}{l}\text { Corporate Sponsorship*Organizational } \\
\text { Cohesiveness }\end{array}$ & & & $-.241^{* *}$ & & \\
\hline & $\mathrm{F}=55.97$ & $\mathrm{~F}=55.06$ & $\mathrm{~F}=52.26$ & $\mathrm{~F}=53.04$ & $\mathrm{~F}=51.71$ \\
& $R^{2}=.529$ & $R^{2}=.537$ & $R^{2}=.539$ & $R^{2}=.488$ & $R^{2}=.508$ \\
\hline
\end{tabular}

$\mathrm{P}<0.05,{ }^{*} \mathrm{P}<0.01, * * * \mathrm{P}<0.001$ shows this value is statistically significant

Figure 1 illustrates the interactive effects that corporate sponsorship and organizational cohesiveness have on turnover intention. We utilized the mean as the benchmark threshold - corporate sponsorship scores that are higher than the average are classified into the high score group and those lower or equal to the average are classified into the low score group. From Figure 1, it is very clear that if the level of organizational cohesiveness remains unchanged, the higher the level of corporate sponsorship, the lower the level of turnover intention. This finding is certainly very exciting. In other words, enterprises can effectively lower employee turnover intention by sponsoring public events.

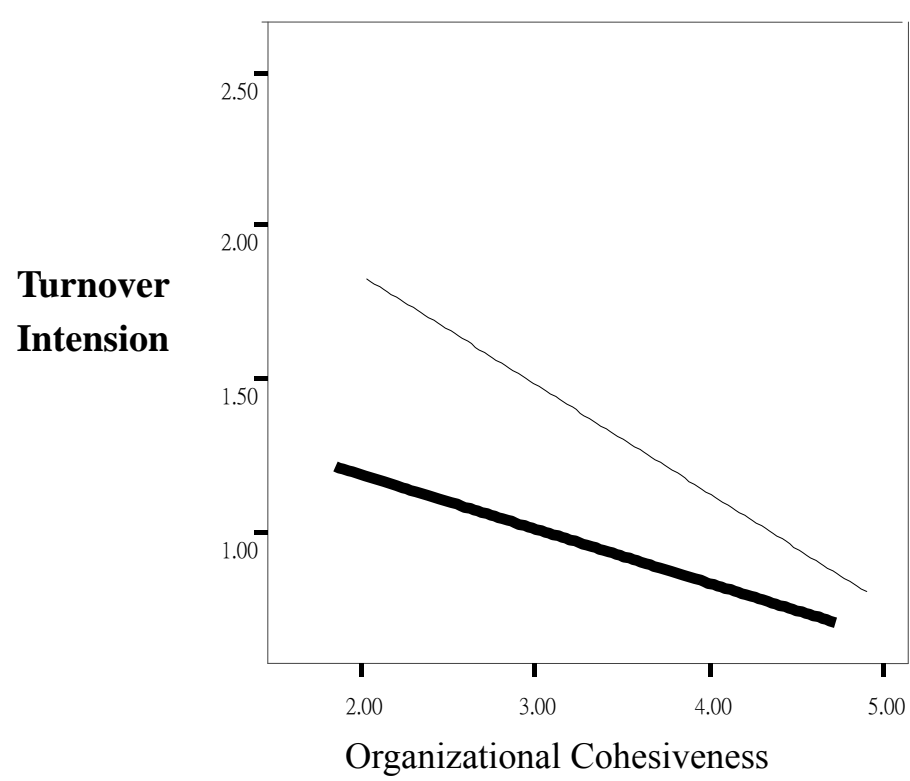

Corporate Sponsorship

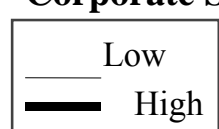

Figure 1. Interactive effects that corporate sponsorship has on organizational cohesiveness and turnover intention 


\section{Discussion}

The result revealed that even though the score of organizational commitment is low among the sample, the hypothesis that organizational commitment and organizational cohesiveness both exert positive influences is supported. As for why organizational commitment is statistically low in this study, future studies can continue this topic and perhaps focus on only particular industries and variables such as seniority, performance and position to identify the cause. In addition, the study revealed that organizational cohesiveness exerts significant negative influence on turnover intention, and this hypothesis is statistically supported. Similar to organizational commitment, the sample also showed a low score of organizational cohesiveness. Generally speaking, the effect of organizational cohesiveness is more obvious in sports or contests. Thus, it is reasonable that organizational cohesiveness is low among corporate employees. On the other hand, an exciting finding is also discovered in this study - turnover intention that employees have will not increase along with corporate sponsorship. Rather, the rise of corporate sponsorship will lower turnover intention. However, if employees are not satisfied with their compensation package, will they still support corporate sponsorship? This is an interesting topic for future studies.

\section{References}

Aryee, S., Wyatt, T., \& Min, M. K. (1991). Antecedents of organizational commitment and turnover intentions. Journal of Social Psychology, 131(4), 545-56. http://dx.doi.org/10.1080/00224545.1991.9713884

Autry, C. W., \& Daugherty, P. J. (2003). Warehouse operations employee: linking person-organization fit, job satisfaction, and coping response. Journal of Business Logistics, 24(1), 171-97. http://dx.doi.org/10.1002/j.2158-1592.2003.tb00036.x

Bloom, P. N., Hoeffler, S., Keller, K. L., \& Meza, C. E. B. (2006). How Social-Cause Marketing Affects Consumer Perceptions. MIT Sloan Management Review, 47(2), 49-55.

Caplan R. D., Cobb S., French J. R. P., Van Harrison R., \& Pinneau S. R. (1975). Job demands and worker health. Cincinnati, OH: National Institute for Occupational Safety and Health, 75-168.

Carrigan, M. (1997). The great corporate give-away-can marketing do good for the do-gooders? European Business Journal, 9, 40-46.

Carron, A. V., \& Brawley, L. R. (1985). The Development to assess cohesion in sports teams. Journal of Sport Psychology, 7, 244-266.

Carron, A. V., Widmeyer, W. N., \& Brawley, L. R. (1985). The development of assess cohesion in sport team: the group environment questionnaire. Journal of Sport Psychology, 7, 244-266.

Chang, H. M. (2008). Relations between team work and innovation in organizations and the job satisfaction of employees: A factor analytic study. International Journal of Management, 25(3), 732-9.

Chelladurai, P., \& Carron, A. V. (1982). Leadership. Ottawa Ontario: Canadian Association of Health, Physical Education and Recreation.

Chidambaram, L., \& Jones, B. (1996). Impact of Communication Media and Computer Support on Group Performance: A Comparison of Face-to-Face and Dispersed Meeting. MIS Quarterly, 17(4), 465-489. http://dx.doi.org/10.2307/249588

Clark R. A., Hartline M. D., \& Jones K. C. (2009). The Effects of Leadership Style on Hotel Employees' Commitment to Service Quality. Cornell Hospitality Quarterly, 50(2), 209-231. http://dx.doi.org/10.1177/1938965508315371

Corey, E. R. (1992). The Development of Markets for New Materials Boston: Division of Research. Graduate School of Business Administration.

Dwight, W. C., \& Richard, L. V. (1997). The complete guide to special event management. Englewood Cliffs: Pren- tice-Hall.

Ferguson, G. H. (1986). Distinguishing Voluntary from Involuntary, Nurse Turnover. Nursing Management, 17(12), 43-44. http://dx.doi.org/10.1097/00006247-198612000-00018

Ferris \& Aranya. (1983). Comparison of Two Organizational Commitment Scale.

Gardner \& Shuman P. (1988). Sponsorship and small business. Journal of Small Business Management, 26, 44-52.

Garkovich, L., \& Greider, T. (1994). Landscape the social construction of nature and the environment. Rural 
Sociology, 59(1), 1-24.

Gooley, T. B. (2001). Mass Customization: How Logistics Makes It Happen. Logistics Management and Distribution.

Gwinner, K. P. (1999). Building Brand Image through Event Sponsorship: The Role of Image Transfer. Journal of Advertising, 28(4), 47-57.

Hom, P., \& Griffeth, R. W. (2000). Employee turnover. Cincinnati, OH: South-Western.

Jaffrey, K. S., Charles, M. F., \& Rajan, V. (1989). Exploring salesperson turnover: A casual model. Journal of Business Research, 18(1), 305-308.

Johnson, M., \& Zinkhan, G. M. (1990). Defining and Measuring company Image. Proceedings of the Thirteenth Annual Conference of the Academy of Marketing Science, 23, 346-350.

Johnston, M. W., \& Futrell C. M. (1989). Functional sales force turn-over: an empirical investigation into the positive effects of turnover. Journal of Business Research, 18(1), 141-157. http://dx.doi.org/10.1016/0148-2963(89)90032-5

Keller, K. L. (1986). Conceptualizing, measuring and managing customer-based brand equity. Journal of Marketing, 57, 1-22. http://dx.doi.org/10.2307/1252054

Lawler, E. J., \& Yoon, J. (1993). Power and the Emergence of Commitment Behavior in Negotiated Exchange. American Sociological Review, 58, 465-81. http://dx.doi.org/10.2307/2096071

Lawler, E. J., \& Yoon, J. (1996). Commitment in Exchange Relations: Test of a Theory of Relational Cohesion. American Sociological Review, 61, 89-108. http://dx.doi.org/10.2307/2096408

LeUnes, A., \& Nation, J. R. (1989). Aggression: Violence in selected sport populations. In A. LeUnes \& J. R. Nation (Eds.), Sport psychology (pp. 208-222). CA: Wadsworth.

McCavarille, R. E., \& Copeland, R. P. (1994). Understanding sport sponsorship through exchange theory. Journal of Sport Management, 8(2), 102-114.

Meenaghan, J. A. (1983). Commercial Sponsorship. European Journal of Marketing, 17(7), 5-74. http://dx.doi.org/10.1108/EUM0000000004825

Meenaghan, T. (1991). Sponsorship-Legitimising the Medium. European Journal of Marketing, 11, 5-1. http://dx.doi.org/10.1108/EUM0000000000627

Meenaghan, T. (2001). Understanding sponsorship effects. Psychology \& Marketing, 18 (2), 95-122. http://dx.doi.org/10.1002/1520-6793(200102)18:2<95::AID-MAR1001>3.0.CO;2-H

Meyer, J. P., Paunonen, S. V., Gellately, I. R., Goffin, R. D., \& Jackson, D. N. (1989). Organizational commitment and job performance: It's the Nature of the Commitment That Counts. Journal of Applied Psychology, 74, 152-156. http://dx.doi.org/10.1037/0021-9010.74.1.152

Michaels, C. E., \& Spector, P. E. (1982). Causes of Employee Turnover: A Test of the Mobley, Griffeth, Hand, and Meglino Model. Journal of Applied Psychology, 67(1), 53-59. http://dx.doi.org/10.1037/0021-9010.67.1.53

Mobley, W. H. (1977). Intermediate Linkages in the Relationship between Job Satisfaction and Employee Turnover. Journal of Applied Psychology, 62, 237-240. http://dx.doi.org/10.1037/0021-9010.62.2.237

Mobley, W. H., Horner, S. O., \& Hollingsworth, A. T. (1978). An evaluation of precursors of hospital employee turnover. Journal of Applied Psychology, 63(4), 408-414. http://dx.doi.org/10.1037/0021-9010.63.4.408

Mobley, W. H., Griffeth, R. W., Hand, H. H., \& Meglino, B. (1978). Review and Conceptual Analysis of the Employee TurnoverProcess. Psychological Bulletin, 86 (3), 517.

Mowday, R. T., Porter, L. W. \& Steers, R. M. (1982). Employee-Organization Linkage- the Psychology of Commitment Absenteeism and Turnover (pp.20-56). New York: Academic Press.

Mullen, B., \& Copper, C. (1994). The relation between group cohesiveness and performance: An integration. Psychological Bulletin, 115, 210-227. http://dx.doi.org/10.1037/0033-2909.115.2.210

O'Reilly, C. A., \& Caldwell, D. (1989). Job choice: The impact of intrinsic and extrinsic factors on subsequent satisfaction and commitment. Journal of Applied Psychology, 65, 559-569. http://dx.doi.org/10.1037/0021-9010.65.5.559

O’Reilly, C. A., Caldwell, D., \& Barnett, W. (1989). Work group demography, social integration, and turnover. 
Administrative Science Quarterly, 34, 21-37. http://dx.doi.org/10.2307/2392984

O'Reilly, C. A., Chatman, J., \& Caldwell, D. F. (1991). People and organizational culture: Aprofile comparison approach to assessing person-organization fit. Academy of Management Journal, 34, 487-516. http://dx.doi.org/10.2307/256404

Porter, L., Steers, R., Mowday, R., \& Boulian, N. (1974). Organizational Commitment, Job Satisfaction, and Turnover among Psychiatric Technicians. Journal of Applied Psychology, 59, 603-609. http://dx.doi.org/10.1037/h0037335

Randall, D. M., Fedor, D. B., \& Longenecker, C. O. (1990). The behavioural expression of organizational $\begin{array}{llll}\text { commitment. Journal of } & \text { Vocational }\end{array}$ http://dx.doi.org/10.1016/0001-8791(90)90028-Z

Robbins, S. P. (1993). Organizational Behavior (4th ed.). New Jersey: Prentice-Hall, Inc.

Robinson, T. T., \& Carron, A. V. (1982). Personal and situational factors associated with dropping out versus maintaining participation in competitive sport. Journal of Sport Psychology, 4, 364-378.

Sackett, P. R., Harris, M. M., \& Orr. J. M. (1986). On Seeking Moderator Variables in the Meta-Analysis of Correlation Data: A Monte Carlo Investigation of Statistical Power and Resistance to Type Error. Journal of Applied Psychology, 71, 302-310. http://dx.doi.org/10.1037/0021-9010.71.2.302

Sandler, D. M., \& Shani, D. (1989). Olympic sponsorship vs. 'Ambush' marketing: Who gets the go. Journal of Advertising Research, 29(4), 9-14.

Schneider, B. (1987). The people make the place. Personnel Psychology, 40, 437-453. http://dx.doi.org/10.1111/j.1744-6570.1987.tb00609.x

Shandler, D. M., \& Shani, D. (1989). Olympic sponsorship vs. "Ambush" marketing: Who gets the gold? Journal of Advertising Research, 11, 9-14.

Smith, C. A., Organ, D.W., \& Near, J. P. (1983). Organizational citizenship behaviors: Its nature and antecedents. Journal of Applied Psychology, 68, 653-663. http://dx.doi.org/10.1037/0021-9010.68.4.653

Speed, R., \& Thompson P. (2000). Determinants of sports sponsorship response. Academy of Marketing Science, 28(2), 226-238. http://dx.doi.org/10.1177/0092070300282004

Stipp, H., \& Schiavone, N. P. (1996). Modeling the impact of Olympic sponsorship on corporate image. Journal of Advertising Research, July/Aug, 22-27.

Stotlar, D. K. (1993). Successful sport marketing. Dubuque, IA: Brown-Benchmark.

Wagner, C. M. (2007). Organizational commitment as a predictor variable in nursing turnover research: literature review. Journal of Advanced Nursing, 60(3), 235-247. http://dx.doi.org/10.1111/j.1365-2648.2007.04421.x

Yousef, D. (2000). Organizational commitment as a mediator of the relationship between Islamic work ethic and attitudes toward organizational change. Human Relation, 53(4), 513-537. http://dx.doi.org/10.1177/0018726700534003 